\title{
CUMULATIVE INDEX
}

\section{Volumes I-XVIII}

\section{SUBJECT MATTER INDEX}

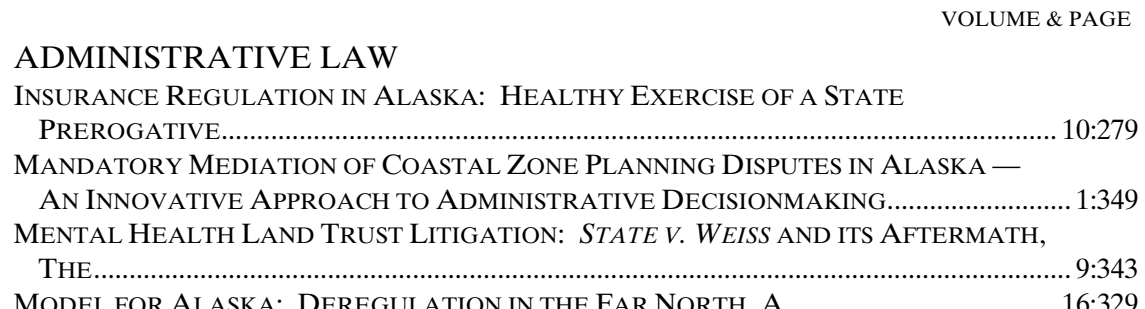

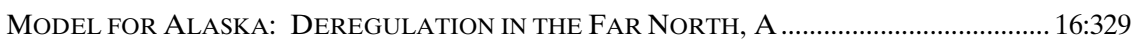

\section{ADMIRALTY}

ANALYSIS OF JURISDICTIONAL ISSUES PRESENTED WHEN STATE-EMPLOYED SEAmen ARe InJured AND SEEK Redress, AN.

ALASKA NATIVES

ALASKA V. NATIVE VILLAGE OF VENETIE: STATUTORY CONSTRUCTION OR JUDICIAL USURPATION? WHY HISTORY COUNTS

ANCSA CORPORATION LANDS AND THE DEPENDENT INDIAN COMMUNITY

CATEGORY OF INDIAN COUNTRY

CANONS OF CONSTRUCTION, STARE DECISIS AND DEPENDENT INDIAN

COMMUNITIES: A TEST OF JUDICIAL INTEGRITY …….................................................. 16:37

CATHOLIC SOCIAL SERVICES, INC. V. C.A.A.: BeSt INTERESTS AND STATUTORY CONSTRUCTION OF THE INDIAN CHILD WELFARE ACT .................................................... 7:203

COMITY OF ERRORS: WHY JOHN V. BAKER IS ONLY A TENTATIVE STEP IN THE Right DiRECTION, A

Culture, Cash or Calories: InTERPReting Alaska Native Subsistence RIGHTS.

ForeWORD to NATIVE LAW SELECTIONS: RECENT DEVELOPMENTS IN FEDERAL INDIAN LAW AS APPLIED TO NATIVE ALASKANS

InDIAN CHILD WELFARE ACT: DOES IT COVER CUSTODy DisPutes AMONG EXTENDED FAMILY MEMBERS?, THE.

INDIAN COUNTRY AND INHERENT TRIBAL AUTHORITY: WILL THEY SURVIVE ANCSA? .................................................................

REVISIONIST HISTORY OF INDIAN COUNTRY, A ............................................................. 14:283

TOWARD A GROUP RIGHTS THEORY FOR REMEDYING HARM TO THE SUBSISTENCE CUlture of Alaska NATIVES..

TRIBAL COURT JURISDICTION AND PUBLIC LAW 280: WHAT ROLE FOR TRIBAL COURTS IN ALASKA?.

TRIBAL POWERS TO REGULATE HUNTING IN ALASKA 
WAIVER OF TRIBAL SOVEREIGN IMMUNITY IN THE CONTRACTUAL CONTEXT:

CONFLICT BETWEEN THE NINTH CIRCUIT AND THE ALASKA SUPREME COURT?, THE.

WARRANTLESS SEARCHES FOR ALCOHOL BY NATIVE ALASKAN VILLAGES: A

PERMISSIBLE EXERCISE OF SOVEREIGN RIGHTS OR AN ASSAULT ON CIVIL

LIBERTIES?

WHEN WORLDS COLLIDE: ALASKA NATIVE CORPORATIONS AND THE

BANKRUPTCY CODE

ALTERNATIVE DISPUTE RESOLUTION

Alaska's MedicAl MALPRACTICE EXPERT AdVISORy PANEL: AsSESSING THE PROGNOSIS.

Alternative Dispute Resolution Strategies in MedicAl Malpractice $9: 429$

BANKRUPTCY

In Re COPPER RIVER SCHOOL DISTRICT: COLleCtIVE BARGAINING AND CHAPTER

9 MUNICIPAL BANKRUPTCY

WHEN WORLDS COLLIDE: AlASKa NATIVE CORPORATIONS AND THE BANKRUPTCY CODE

BOOK REVIEWS

REVIEW OF ALASKA NATIVES AND AMERICAN LAWS, BY DAVID S. CASE \& DAVID AVRAHAM VOLUCK.

\section{CIVIL PROCEDURE}

Alaska Rule 26: A Quixotic Venture into the World of MANDAtory DISCLOSURE.

Alaska Rule of Civil Procedure 11: A Proposed Amendment And a Guide FOR APPLICATION AND INTERPRETATION. ..

AlASKA's ENGLISH RULE: ATTORNEY's FEE SHIFTING IN CIVIL CASES .......................... 13:33

Alaska's Medical Malpractice EXPert Advisory PANEL: Assessing the PROGNOSIS

BLOWING HOT $A N D$ COLD ON THE FROZEN TUNDRA: A REVIEW OF ALASKA'S QUASI-ESTOPPEL DOCTRINE

Choice of LaW In Alaska: A SuRviVal Guide FOR Using THE SECOND RESTATEMENT.

CIVIL RULE 90.3: JUdiCIAL DisCRETION UNDER ALASKA'S CHILD SUPPORT GUIDELINE

COMPULSORY JOINDER OF PARTIAL SUBROGEES: IMPLICATION OF THE ALASKA RULE

ENFORCEABILITY OF FORUM-SELECTION CLAUSES AFTER STEWART ORGANIZATION, INC. V. RICOH CORPORATION, THE

IMPACT OF ECONOMIC INCENTIVES ON THE AWARD OF ATTORNEY'S FEES IN PUBLIC INTEREST LITIGATION, THE

JURISDICTION AND THE HUNT: SUBSISTENCE REGULATION, ANILCA AND TOTEMOFF

LAWRENCE V. LAWRENCE: THe Use OF Rule 60(B) Motions Based UPON Post JUDGMENT CHANGES IN CONTROLLING LAW

Litigation-ENDing SANCTIONS: ALASKa COURTS' USE OF RULE 37.

PRELIMINARY INJUNCTIONS AS RELIEF FOR SUBSTANTIAL PROCEDURAL Violations of ENVIRONMENTAL STATUTES: AMOCO PRODUCTION CO. $\mathrm{V}$. VILLAGE OF GAMBELL

Rule 82 ReVISITED: ATtORNEy FeE SHIFTING IN ALASKA 
COMMERCIAL LAW

ALASKA DisTRESS LAW IN THE COMMERCIAL CONTEXT: ANCIENT RELIC OR FUNCTIONAL REMEDY?. $10: 33$

RILEY V. NORTHERN COMMERCIAL: COMMERCIAL RATIONALE TRIUMPHS OVER STATUTORY INTERPRETATION.

\section{CONSTITUTIONAL LAW}

ALASKa EQUal PRotection: CONSTITUTIONAL LAW OR COMMON LAW?..... $15: 209$

Alaska MARriage AMENDMENT: The PEOPLE's ChOICE ON THE LAST Frontier, THE.

ALASKA PACIFIC ASSURANCE CO. V. BROWN: THE RIGHT TO TRAVEL AND THE

CONSTITUTIONALITY OF CONTINUOUS RESIDENCY REQUIREMENTS

ALASKA'S CRIMINALIZATION OF REFUSAL TO TAKE A BREATH TEST: IS IT A PERMISSIBLE WARRANTLESS SEARCH UNDER THE FoURTH AMENDMENT? ................ 5:263

Alaska's Right to Privacy Ten Years After Ravin V. State: Developing A JURISPRUDENCE OF PRIVACY ................................................................................ 2:159

COMPelling Testimony in AlASKa: The COMING ReJection of USE AND DERIVATIVE USE IMMUNITY .................................................................................... 3:229

CONSTITUTIONALITY OF ALASKA's TAKEOVER BID DISCLOSURE ACT, THE .................... 1:335

CONSTITUTIONALITY OF SOBRIETY CHECKPOINTS IN ALASKA, THE .................................. 8:227

Custodial Consents to SEARCh in Alaska: A Waiver APPROACH, at Least WHERE MIRANDA WARNINGS ARE ABSENT? .................................................................. 3:125

DRUG TESTING OF PUBLIC AND PRIVATE EMPLOYEES IN ALASKA .................................. 5:133

FreE EXERCISE, FAIR Housing AND MARITAL STATUS — AlASKAN STYLE................. 12:335

FREEDOM OF RELIGION IN ALASKA: INTERPRETING THE ALASKA CONSTITUTION....... 5:237 InVESTIGATIVE STOPS IN ALASKA: CAN COLEMAN SURVIVE A MULTIFACTORED BALANCE? $7: 381$

JUSTICE RABINOWITZ AND PERSONAL FREEDOM: EVOLVING A CONSTITUTIONAL

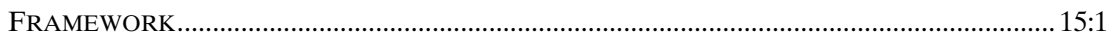

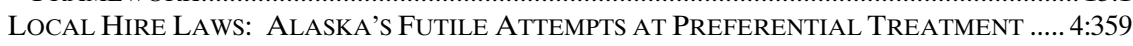

NORTHERN LIGHTS — EQUAL PROTECTION ANALYSIS IN ALASKA....................................... 3:1

POLICE DECEPTION OF A CRIMINAL SUSPECT'S ATTORNEY: AN ANALYSIS OF MORAN V. BURBINE UNDER THE ALASKA CONSTITUTION ............................................ 5:161

Private Rights Versus Public Power: The Role of State Action in Alaska CONSTITUTIONAL JURISPRUDENCE.

PRotection of CHILD Witnesses AND THE Right OF CONFRONTATION: A

BALANCING OF INTERESTS.

RESTITUTION, RETRIBUTION, AND THE CONSTITUTION................................................... 7:333

SANITY IN ALASKA: A CONSTITUTIONAL ASSESSMENT OF THE INSANITY DEFENSE STATUTE

STANDARDS OF MATERIALITY GOVERNING THE PROSECUTORIAL DUTY TO

DISCLOSE EVIDENCE TO THE DEFENSE.

Tale of Two Courts: The Alaska Supreme Court, THE United States SUPREME COURT, AND RETROACTIVITY, A

WARRANTLESS SEARCHES FOR ALCOHOL BY NATIVE ALASKAN VILLAGES: A

PERMISSIBLE EXERCISE OF SOVEREIGN RIGHTS OR AN ASSAULT ON CIVIL LIBERTIES?

CONSTITUTION - ALASKA

AlASKa EQUAL PROTECTION: CONSTITUTIONAL LAW OR COMMON LAW?...... 15:209

Alaska MARriage AMENDMENT: THE PEOPLE's ChOICE ON THE LAST Frontier, THE. 
ALASKA'S CAP ON NONECONOMIC DAMAGES: UNFAIR, UNWISE AND

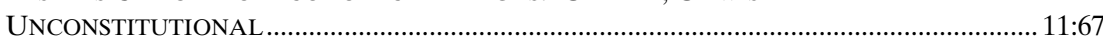

ALASKA'S MENS REA REQUIREMENTS FOR STATUTORY RAPE ....................................... 9:377

AlaskA's Right to Privacy Ten Years After RaVIN V. STAte: Developing A JURISPRUDENCE OF PRIVACY ......

"Be it Enacted by the People of the State of Alaska. . ." - A

PRACTITIONER'S GUIDE TO ALASKA'S INITIATIVE LAW .... 9:279

COMPELling TESTIMONY IN AlASKa: THE COMING REJECTION OF USE AND

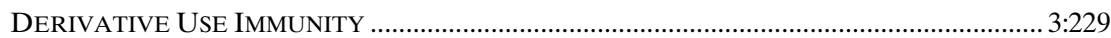

DRUG TESTING OF PUBLIC AND PRIVATE EMPLOYEES IN ALASKA ……............................... 5:133

FreE EXERCISE, FAIR Housing AND MARITAL STATUS — AlASKAN STYLE................ 12:335

FREEDOM OF RELIGION IN ALASKA: INTERPRETING THE ALASKA CONSTITUTION ........ 5:237

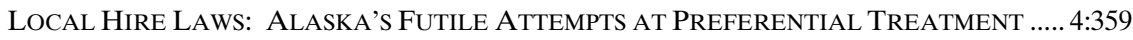

POLICE DECEPTION OF A CRIMINAL SUSPECT'S ATTORNEY: AN ANALYSIS OF MORAN V. BURBINE UNDER THE ALASKA CONSTITUTION... . 5:161

PRIVACY VS. PRACTICALITY: SHOULD Alaska AdOPT THE LEON GOOD FAITH EXCEPTION? $10: 143$

TAle of Two Courts: The Alaska Supreme Court, the United States SUPREME COURT, AND RETROACTIVITY, A ....................................................................... 9:305

RaVin ReVisited: Do Alaskans STILl HaVe the Constitutional Right to POSSESS MARIJUANA IN THE PRIVACY OF THEIR HOMES?

SELF-INCRIMINATION ProteCtion Under THE Alaska CONSTITUTION: A DESCRIPTIVE ANALYSIS

SMOTHERING FrEEdom OF ASSOCIATION: THE ALASKA SUPREME COURT ERRS IN UPHOLDING THE STATE'S BLANKET PRIMARY STATUTE $14: 523$

WELCOME TO THE “LAST FrontIER,” PROFESSOR GARDNER: Alaska's INDEPENDENT APPROACH TO STATE CONSTITUTIONAL INTERPRETATION

\section{CONTRACTS}

ALASKA's PUBLIC DUTY EXCEPTION: RESTRAINTS UPON THE RIGHT TO CONTRACTUAL INDEMNITY

DOCTRINE OF THE IMPLIED INSURED IN ALASKA: RECENT DEVELOPMENTS CONCERNING THIRD PARTIES TO INSURANCE CONTRACTS, THE

ENFORCEABILITY OF FORUM-SELECTION CLAUSES AFTER STEWART ORGANIZATION, INC. V. RICOH CORPORATION, THE

IMPLIED COVENANT OF GOOD FAITH AND FAIR DEALING IN ALASKA: ONE COURT'S LICENSE TO OVERRIDE CONTRACTUAL EXPECTATIONS, THE .....

MONITORING THE EMPLOYMENT CONTRACT IN ALASKA.

MUNICIPALITY OF ANCHORAGE V. HITACHI CABLE, LTD. — TIME FOR ADOPTION OF A VOID CONTRACT REMEDY FOR ALASKA PUBLIC CONTRACTING AUTHORITIES...

OUt on PARol?: A CRITICAl EXAMINATION OF THE Alaska SuPREME COURT'S APPLICATION OF THE PAROL EVIDENCE RULE........................................................... 11:407

Statute of Limitations for Professional MaLPRACTICE IN Alaska After LEE HOUSTON \& ASSOCIATES, LTD. V. RACINE, THE.

CORPORATE LAW

Alaska Corporations Code: The Forty-Ninth State Claims the Middle GROUND, THE.

Control and/OR Misconduct: Clarifying the Test For Piercing the CORPORATE VEIL IN ALASKA .

CONVERTING TO A LIMITED LIABILITY COMPANY: CONSIDERATIONS FOR ALASKA BUSINESS ORGANIZATIONS. 
CREATION, OPERATION, AND DisSOLUTION OF A LIMITED PARTNERSHIP IN

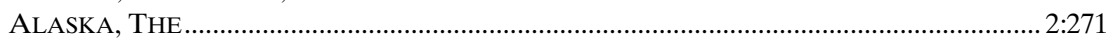

SHAREHOLdERS' AgreEMENTS IN ALASKa AFTER HIKITA V. NICHIRO GYOGYO

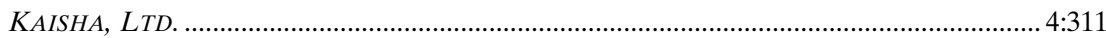

CRIMINAL LAW

ALASKA'S INSANITY DEFENSE AND THE “GUILTY BUt MENTALLy ILL” VeRdict.......... 4:171

ALASKA'S MENS REA REQUIREMENTS FOR STATUTORY RAPE ........................................ 9:377

CONSCIOUSNESS OF WRONGDOING: MENS REA IN ALASKA ................................................ 1:1

DEVELOPMENT OF APPELLATE SENTENCING LAW IN ALASKA, THE ................................ 7:265

LESSER-INCLUDED OFFENSES IN ALASKA: STATE V. MINANO …........................................ 3:199

More THAN Just a Private AFFAIR: Is THE PRACTICE OF INCARCERATING

Alaska Prisoners IN PRIVATE OUT-OF-STATE PRISONS UNCONSTITUTIONAL?..... 17:319

NitZ V. STATE: SKeWING THE EVIDENTIARY RULES To PROSECUTE CHILD

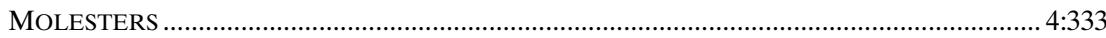

OVERVIEW OF JUVENILE DELINQUENCY LAW IN ALASKA, AN .......................................... 8:1

PEARS V. STATE: AN IMPROPER APPLICATION OF ALASKA'S CURRENT LAW TO

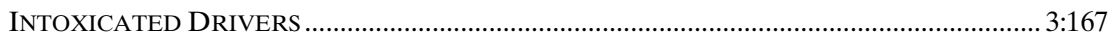

POST-PlEA APPEAL OF “DisPositIVE” ISSUES: “ThERE’S GLORY FOR YOU!”................. 5:221

PRESUMPTIVE SENTENCING IN ALASKA........................................................................ 2:227

RAVIN REVISITED: Do Alaskans STILl HAVE THE CONSTITUTIONAL Right TO

PoSSESS MARIJUANA IN THE PRIVACY OF THEIR HOMES?.............................................. 15:315

RE-EVALUATION OF ALASKA's PLEA BARGAINING BAN, A ……......................................... 8:27

RESTITUTION, RETRIBUTION, AND THE CONSTITUTION........................................................ 7:333

STANDARdS OF MATERIALITY GOVERNING THE PROSECUTORIAL DUTY TO

DISCLOSE EVIDENCE TO THE DEFENSE.

\section{CRIMINAL PROCEDURE}

Admissibility of Prior Bad Acts in SeXual Assault Cases Under Alaska

Rule of EVIDENCE 404(B) — AN EMERGING Double STANDARD, THE ...................... 5:193

CONSTITUTIONALITY OF SOBRIETY CHECKPOINTS IN ALASKA, THE .................................... 8:227

Custodial Consents to Search in Alaska: A Waiver ApProach, AT Least

WHERE MIRANDA WARNINGS ARE ABSENT? .................................................................. 3:125

DETERring DEFENDANTS FROM TAKING THE STAND: THE EXTENSION OF STATE $V$.

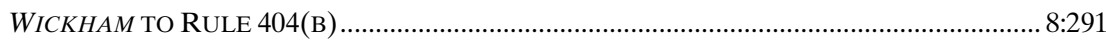

DEVELOPMENT OF APPELLATE SENTENCING LAW IN ALASKA, THE ................................. 7:265

INCONSISTENT JURY VERDICTS RETURNED ON A MULTIPLE COUNT INDICTMENT OF

A SINGLE DEFENDANT

InVestigative Stops in Alaska: CAN Coleman SuRvive A Multifactored

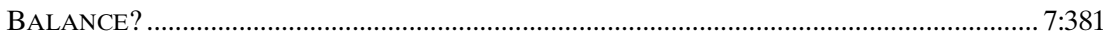

Police DECEPTION OF A CRIMINAL SUSPECT'S ATtORneY: AN ANALYSIS OF

MORAN V. BURBINE UNDER THE ALASKA CONSTITUTION ............................................... 5:161

POST-PlEA APPEAL OF “DisPOSITIVE” ISSUES: “THERE’s GLORY FOR YOU!”.................. 5:221

PRIVACY VS. PRACTICALITY: SHOULD AlASKa AdOPT THE LEON GOOD FAITH

EXCEPTION?

PRotection OF CHILD WitNESSES AND THE Right OF CONFRONTATION: A

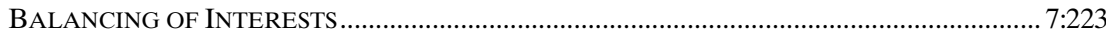

RE-EVALUATION OF ALASKA's PLEA BARGAINING BAN, A …............................................ 8:27

REPORTORIAL POWER OF THE ALASKA GRAND JURY, THE ............................................. 3:295

RETHINKING MANIFEST INJUSTICE: REFLECTIONS UPON THE DECISIONS OF THE

THREE-JUdGE SENTENCING PANEL................................................................................ 5:1

SANITY IN ALASKa: A CONSTITUTIONAL ASSESSMENT OF THE INSANITY DEFENSE

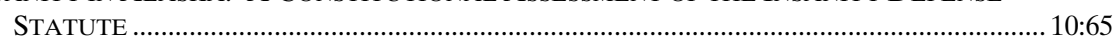


SIDESTEPPING SCOTT: MODIFYING CRIMINAL DisCOVERY IN ALASKA

STANDARDS OF MATERIALITY GOVERNING THE PROSECUTORIAL DUTY TO

DISCLOSE EVIDENCE TO THE DEFENSE.

WARRANTLESS SEARCHES FOR ALCOHOL BY NATIVE ALASKAN VILLAGES: A

PERMISSIBLE EXERCISE OF SOVEREIGN RIGHTS OR AN ASSAULT ON CIVIL

LIBERTIES?

DUE PROCESS, COMMON LAW

ALASKA's “QUASI-PUBliC” HosPitAls: THE IMPLICATIONS OF STORRS

\section{EDUCATION}

Alaska Supreme Court AND the Rights of Public SCHOOL TEACHERS AS

EMPLOYEES: A SUGGESTED RESPONSE TO JUdiCIAL LIMITATION OF COLLECTIVE

BARGAINING RIGHTS, THE

IN RE COPPER RIVER SCHOOL DISTRICT: COLLECTIVE BARGAINING AND CHAPTER 9 MUNICIPAL BANKRUPTCY

\section{EMPLOYMENT}

AFTER-ACQUIRED EVIDENCE IN EMPLOYMENT CASES IN ALASKA: AN

ALTERNATIVE APPROACH

After ACQuiring AN AudienCE: A BRIEF RePly to THE June 2001 CRITIQue

REGARDING AFTER-ACQUIRED EVIDENCE

Alaska Supreme Court AND THE Rights of Public SCHOOl Teachers as

EMPLOYEES: A SugGESTED RESPONSE TO JUdiCIAL LiMITATION OF COLLECTIVE

BARGAINING RIGHTS, THE....

Bad Samaritans Make Dangerous Precedent: The Perils of Holding an

EMPLOYER LIABLE FOR AN EMPLOYEE'S SEXUAL MISCONDUCT ...

BRIEF ANALYSIS OF AFTER-ACQUIRED EVIDENCE IN EMPLOYMENT CASES: A

PROPOSED MODEL FOR ALASKA (AND POINTS SOUTH), A

DRUG TESTING OF PUBLIC AND PRIVATE EMPLOYEES IN ALASKA ..................................... 5:133

EMPLOYMENT AT Will IN ALASKA: THE QUESTION OF PUBLIC POLICY TORTS ............. 6:269

EMPLOYMENT AT WILL: THE “AMERICAN RULE” AND ITS APPLICATION IN

ALASKA

EMPLOYMENT DisCRIMINATION LAW - STRAND V. PETERSBURG PUBLIC SCHOOL AND FRIDRIKSSON V. ALASKA USA FEDERAL CREDIT UNION: THE SUPREME COURT CHARTS AN UNCERTAIN COURSE.

GOOD, THE BAD, AND THE UGLY: DRUG TESTING BY EMPLOYERS IN ALASKA, THE . 16:297 IN RE COPPER RIVER SCHOOL DISTRICT: COLLECTIVE BARGAINING AND CHAPTER

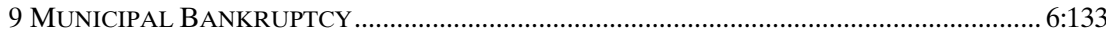

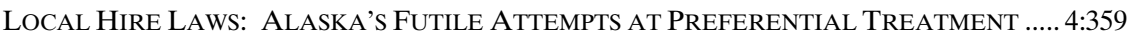
Modest Proposal: THE "ReAsonable Victim" STANDARD and Alaska EMPLOYERS' AFFIRMATIVE DEFENSE TO VICARIOUS LIABILITY FOR SEXUAL HARASSMENT, A

MONITORING THE EMPLOYMENT CONTRACT IN ALASKA

SeXual Abuser Insurance in Alaska: A Note on ST. PAUl FIRE \& MARINE INS. CO. V. F.H.; K.W.

SHELTER FROM THE STORM: THE NEED FOR WRONGFUl Discharge LEGISLATION

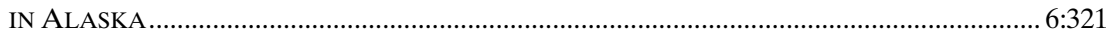

SOMETHING MORE IMPORTANT THAN MONEY — VOCATIONAL REHABILITATION IN WORKER'S COMPENSATION CASES .................................................................................. $3: 49$

THOMAS V. ANCHORAGE TELEPHONE UTILITY: Alaska TACKLES GENDER-BASED WAGE DISCRIMINATION..... 
WALT-ZING THROUGH AN EMPLOYMENT TERMINATION: Is THERE A DUTY TO INVESTIGATE BEFORE DISCHARGING IN ALASKA? $11: 231$

\section{ENVIRONMENTAL LAW/NATURAL RESOURCES}

AMOCO PRODUCTION CO. V. VILLAGE OF GAMBELL AND MOTOR VEHICLE MANUFACTURERS ASSOCIATION V. STATE FARM MUTUAL AUTOMOBILE INSURANCE CO.: AUTHORITY WARRANTING RECONSIDERATION OF THE SubSTANTIVE GOALS OF THE NATIONAL ENVIRONMENTAL POLICY ACT .

"EQUAL ACCESS" TO ALASKA'S FISH AND WILDLIFE 11:277

HAMMOND V. NORTH SLOPE BOROUGH: THE ENDANGERED SPECIES ISSUE - AN EXERCISE IN JUDICIAL LETHARGY

High STAKES IN THE High ARCTIC: JURISDICTION AND COMPENSATION FOR OIL POLLUTION FROM OFFSHORE OPERATIONS IN THE BEAUFORT SEA...

Limits OF LiABILITY: CAN ALASKa OIL SPILl Victims RECOVER PURE ECONOMIC LOSS?, THE

MAJOR ISSUES IN DEVELOPING ALASKA'S OUTER CONTINENTAL SHELF OIL AND

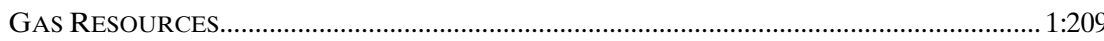

MANAGING Alaska's CoAstal DeVElopment: State REVIEW of FEDERAL OIL AND GAS LEASE SALES.

MANAging SEnSitive Ecosystems: HonsingER V. STATE AND THE NEED FOR FLEXIBILITY IN THE RULES OF REAL PROPERTY ....

MANDATORY MEDIATION OF COASTAL ZONE PlANNING DisPUTES IN ALASKA AN INNOVATIVE APPROACH TO ADMINISTRATIVE DECISIONMAKING.

PRELIMINARY INJUNCTIONS AS RELIEF FOR SUBSTANTIAL PROCEDURAL VIOLATIONS OF ENVIRONMENTAL STATUTES: AMOCO PRODUCTION CO. $\mathrm{V}$. VILLAGE OF GAMBELL.

SPIRIT OF '76: DOES PRESIDENT CLINTON'S ROADLESS LANDS DIRECTIVE VIOLATE THE SPIRIT OF THE NATIONAL FOREST MANAGEMENT ACT OF 1976?, THE

STRUGGLE FOR ALASKA's SUBMERGED LAND, THE

\section{EVIDENCE}

Admissibility of Prior Bad Acts in SeXual Assault Cases Under Alaska

Rule OF EVIDENCE 404(B) - An EMERging Double STANDARD, The...

CONSTRUCTION AND ADMISSIBILITY OF INSURANCE POLICIES THAT PROVIDE Coverage for Punitive Damage Awards, THe.

DETERRING DEFENDANTS FROM TAKING THE STAND: THE EXTENSION OF STATE $V$. WICKHAM TO RULE 404(B).....

EXPloitation OF Trust: THE PSyChotheraPIST-PATIENT PRIVILEGE IN AlASKA

AS APPLIED TO PRISON GROUP THERAPY, THE.

MOLESTERS $4: 333$

On A Collision Course: Pure Propensity EVIDENCE AND Due Process IN ALASKA

SIDESTEPPING SCOTT: MODIFYING CRIMINAL DISCOVERY IN ALASKA ............................ 15:33

STANDARDS OF MATERIALITY GOVERNING THE PROSECUTORIAL DUTY TO DISCLOSE EVIDENCE TO THE DEFENSE..

STRICT LIABILITY AND THE ADMISSIBILITY OF EVIDENCE OF SUBSEQUENT REMEDIAL MEASURES UNDER EVIDENCE RULE 407

FAMILY LAW

Abandonment V. Adoption: Terminating Parental Rights And the Need FOR DISTINCT LEGAL INQUIRIES.

Alaska Marriage Amendment: The PeOPle's Choice on the LAST Frontier, THE 
CATHOLIC Social SERVICES, INC. V. C.A.A.: Best INTERESTS AND STATUtory

CONSTRUCTION OF THE INDIAN CHILD WELFARE ACT .. $7: 203$

CIVIL RUle 90.3: JUdiCIAL DisCRETION UNDER ALASKA's CHILD SUPPORT GUIDELINE

Hitting Deadbeat Parents Where it Hurts: "Punitive” Mechanisms in

CHILD SUPPORT ENFORCEMENT

IMPROVING THE COURT PROCESS FOR ALASKA'S CHILDREN IN NEED OF AID

INDIAN CHILD Welfare ACT: Does IT COVER CUSTODy DisPutes AMONG

EXTENDED FAMILY MEMBERS?, THE.

LIABILITY OF THE STATE AND ITS EMPLOYEES FOR THE NEGLIGENT INVESTIGATION OF CHILD ABUSE REPORTS …………………………............................................. 10:40

NELSON V. NELSON: A PROPOSAL FOR EQUITABLE DistribUtion OF THE

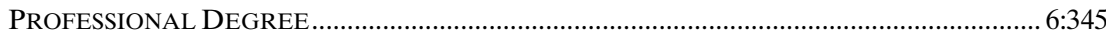

OVERVIEW OF JUVENILE DELINQUENCY LAW IN ALASKA, AN ............................................. 8:1

PROTECTING ALASKA's CHILDREN FROM NEGLECT: THE APPROPRIATE

LEGISLATIVE RESPONSE TO IN RE S.A. AND R.J.M. V. STATE ….................................... 14:501

Protection of CHILD WitNESSES AND THE Right OF CONFRONTATION: A

BALANCING OF INTERESTS

TOWARD A COMPENSATORY MODEL OF ALIMONY IN ALASKA ........................................ 12:101

VisitATION RIGHTS FOR NATURAL PARENTS AFTER STEPPARENT ADOPTION ............... 1:319

WANBERG V. WANBERG: CHARACTERIZATION OF Property FOR THE PURPOSE OF EQUITABLE DISTRIBUTION

\section{FEDERALISM}

MATTER Of EXPECTATIONS: INTERPRETING THE STATUTORY PREEMPTION OF

LOCAL ASSISTANCE TO FEDERAL FIREARMS REgUlators, A

Tale of Two Courts: The Alaska Supreme Court, the United States

SUPREME COURT, AND RETROACTIVITY, A

FISHERIES

MAJOR ISSUES IN DEVELOPING ALASKA's OUTER CONTINENTAL SHELF OIL AND

GAS RESOURCES.

HOSPITALS/PUBLIC HEALTH

ALASKA's “QUASI-PUBLIC" HOSPITALS: THE IMPLICATION OF STORRS..

EIDELSON V. ARCHER: EXHAUSTION OF REMEDIES IN A PRIVATE HOSPITAL

Public Health Improvement Process In Alaska: Toward a Model Public Health Law, THE.

INDIAN POLICIES

(SEE ALASKA NATIVES)

\section{INSURANCE LAW}

CONSTRUCTION AND ADMISSIBILITY OF INSURANCE Policies THAT PROVIDE COVERAGE FOR PUnitive Damage AwARds, THE

DOCTRINE OF THE IMPLIED INSURED IN ALASKA: RECENT DEVELOPMENTS CONCERNING THIRD PARTIES TO INSURANCE CONTRACTS, THE

Insurance Regulation In Alaska: HeAlthy EXERCiSE of A STATE PREROGATIVE

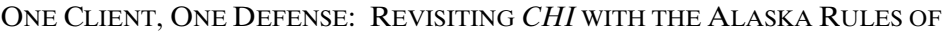
PROFESSIONAL CONDUCT ....

Sexual Abuser Insurance in Alaska: A Note on ST. PAUl Fire \& MARINE INS. CO. V. F.H.; K.W. 


\section{JUDICIARY}

JUDICIAL DISQUALIFICATION IN ALASKA COURTS

JURIES

INCONSISTENT JURY VERDICTS RETURNED ON A MULTIPLE COUNT INDICTMENT OF

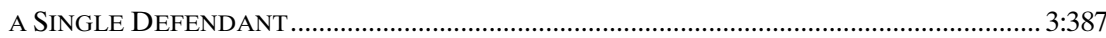

REPORTORIAL POWER OF THE ALASKA GRAND JURY, THE ............................................ 3:295

\section{JUVENILES}

OVERVIEW OF JUVENILE DELINQUENCY LAW IN ALASKa, AN.. $8: 1$ SHIFTING AWAY FROM REHABILITATION: STATE V. LADD'S EQUAL PROTECTION

CHALLENGE TO ALASKA'S AUtOMATIC WAIVER LAW... $15: 367$

\section{LABOR LAW}

Local Hire Laws: AlaskA’s Futile Attempts at Preferential Treatment ..... 4:359

\section{LEGAL PROFESSION}

ADOPTION OF THE ABA STANDARDS FOR IMPOSING LAWYER SANCTIONS BY THE

Alaska SuPREME COURT - IN RE BUCKALEW, THE.

Alaska Rule of Civil Procedure 11: A Proposed AMENDMENT AND A Guide

FOR APPLICATION AND INTERPRETATION .................................................................. 3:361

ASSIGNABILITY OF LEGAL MALPRACTICE CLAIMS...................................................... 14:141

IMPACT OF ECONOMIC INCENTIVES ON THE AWARD OF ATTORNEY'S FEES IN

PUBLIC INTEREST LITIGATION, THE …………………................................................. 1:189

REVOLT IN THE RANKS: THE GREAT Alaska COURT-BAR Fight, A.................................. 13:1

STATUTE of Limitations For PROFESSIONAL MALPRACTICE IN ALASKA AFTER

LEE HOUSTON \& ASSOCIATES, LTD. V. RACINE, THE

\section{OIL AND GAS}

MAJOR ISSUES IN DEVELOPING ALASKA's OUTER CONTINENTAL SHELF OIL AND GAS RESOURCES.

Managing Alaska’s CoAstal DeVElopMent: State ReVIEW of Federal OIL AND GAS LEASE SALES.

POLITICAL PROCESS

ANCHORAGE: GAMING CAPITAL OF THE PACIFIC RIM $17: 343$

ASPEN EXPLORATION CORP. V. SHEFFIELD: THE STATUS OF OFFICIAL IMMUNITY IN

ALASKA

MEINERS V. BERING STRAIT SCHOOL DISTRICT AND THE RECALl OF PUBLIC

OFFICERS: A PROPOSAL FOR LEGISLATIVE REFORM.

PRISON OVERCROWDING IN ALASKA: A LEGISLATIVE RESPONSE TO THE CLEARY

SETTLEMENT

\section{PROPERTY}

ALASKa Distress Law In THE COMMERCIAL CONTEXT: ANCIENT RELIC OR FUNCTIONAL REMEDY?

ALASKA LANDS ACT'S INNOVATIONS IN THE LAW OF ACCESS ACROSS FEDERAL

LANDS: You CAN GET THERE From HERE, THE...

ANCSA CORPORATION LANDS AND THE DEPENDENT INDIAN COMMUNITY

CATEGORY OF INDIAN COUNTRY .

Clouds ARE Lifting: The Problem of Title to SubMERGEd LANDS In AlASKA, THE

EASEMENT CONDEMNATION AND STATE V. DOYLE: FAIR MARKET VALUE

WITHOUT A MARKET 
JURISDiction AND THE Hunt: SUbSISTENCE REgUlATION, ANILCA AND TOTEMOFF. $14: 115$

MANAging SENSITIVE ECOSYSTEMS: HoNSINGER V. STATE AND THE NEED FOR

FLEXIBILITY IN THE RULES OF REAL PROPERTY .

Mental Health Land Trust Litigation: State $V$. WeisS AND Its Aftermath, THE.

Pouring NonProbate Assets InTO A TeSTAMENTARY Trust: A Half-

PROTECTED ACTIVITY IN ALASKA.

ROSENBERG V. SMIDT: DRAMATIC RAMIFICATIONS FOR NONJUDICIAL

FORECLOSURE SALES IN ALASKA..

SelF-Settled SPENDTHRIfT Trusts and the Alaska Trust Act: Has Alaska

MOVED OFFSHORE?. . 5:357

Standing to Challenge the Disposition of Land in Alaska: A Proposed

REMEDY FOR THE INADEQUACIES IN THE CURRENT CASE LAW....................................... 2:393

State of CAVEAt EMPTOR IN Alaska As It APPlies to ReAl Property, THE ........ 13:237

STRUGGLE FOR ALASKA'S SUBMERGED LANDS, THE ……................................................... 5:69

TAXING IsSUE: ARE LIMITED ENTRY FISHING PERMits Property?, A ….......................... 9:93

WANBERG $V$. WANBERG: CHARACTERIZATION OF Property FOR the PURPose OF

EQUITABLE DISTRIBUTION ...................................................................................... 1:143

"WhEN IN NOME . . . .": CUSTOM, CUlture AND THE ObJECTIVE STANDARD IN

ALASKAN ADVERSE POSSESSION LAW

\section{REMEDIES}

ALASKA's APPORTIONMENT OF DAMAgES STATUTE: PROBLEMS FOR LitigANTS $9: 1$

ALASKA's PUBLIC DUTY EXCEPTION: RESTRAINTS UPON THE RIGHT TO

CONTRACTUAL INDEMNITY

EIDELSON V. ARCHER: EXHAUSTION OF REMEDIES IN A PRIVATE HOSPITAL ................. 1:277

EVALUATION OF EARNINGS LOSS IN ALASKA COURTS: THE IMPLICATIONS OF

BEAULIEU AND GUINN, THE

MUNICIPALITY OF ANCHORAGE V. HITACHI CABLE, LTD. - TIME FOR ADOPTION OF A VOID CONTRACT REMEDY FOR ALASKA PUBLIC CONTRACTING AUTHORITIES.....

SURVEY OF FEDERAL TAX COLLECTION PROCEDURE: RightS AND REMEDIES OF

TAXPAYERS AND THE INTERNAL REVENUE SERVICE, A

TORT LOSS ALlOCATION AMONG JOINT TORTFEASORS IN ALASKA: A CALL FOR COMPARATIVE CONTRIBUTION.

TOWARD A GROUP RIGHTS THEORY FOR REMEDYING HARM TO THE SUBSISTENCE

CUlture of Alaska NATIVES.

\section{SECURITIES LAW}

CONSTITUTIONALITY OF ALASKA's TAKEOVER BID DisClosure ACT, THE..... $1: 335$

CREDITORS' vs. DEBTORS' RightS UNDER AlASKA FOREClOSURE LAW: WHICH

WAY DOES THE BALANCE SWING?

DEFINING AN “INVESTMENT CONTRACT” FOR PURPOSES OF ALASKa BLUE SKY LAW: HAVE THE ALASKa COURTS STRETCHED THEIR TEST BEYOND MEANINGFUL APPLICATION?

\section{SENTENCING}

DeVelopment of ApPellate Sentencing in Alaska, The

PRESUMPTIVE SENTENCING IN AlASKA.

Prison OVERCROWDING IN ALASKA: A LEgISLATIVE RESPONSE TO THE CLEARY SETTLEMENT 


\section{TAX}

SURVEY OF FEDERAL TAX COLLECTION PROCEDURE: RightS AND REMEDIES OF

TAXPAYERS AND THE INTERNAL REVENUE SERVICE, A. $3: 269$

TAXING Issue: ARE LIMITED ENTRy Fishing Permits Property?, A

\section{TORTS}

AbANDONMENT V. ADOPTION: TERMinating PARENTAl Rights AND the NEED FOR DISTINCT LEGAL INQUIRIES.

AlaskA's APPORTIONMENT OF DAMAgES STATUTE: Problems FOR LitigANTS ............ 9:1

ALASKA's CAP ON NON-ECONOMIC DAMAGES: UNFAIR, UNWISE AND

UNCONSTITUTIONAL

AlaskA's MEDiCAl MALPRACTICE EXPERT AdVISORY PANEL: ASSESSING THE PROGNOSIS

ALternative DisPute RESOLUtion STRATEGIES IN MEDICAL MALPRACTICE............ 9:429

ANALYSIS OF JURISDICTIONAL ISSUES PRESENTED WHEN STATE-EMPLOYED SEAMEN ARE INJURED AND SEEK REDRESS, AN.

ASPEN EXPLORATION CORP. V. SHEFFIELD: THE STATUS OF OFFICIAL IMMUNITY IN ALASKA …........................................................................................................ $7: 187$

Bad SAMARITANS MaKe Dangerous Precedent: The PERILs OF Holding AN EMPLOYER LIABLE FOR AN EMPLOYEE'S SEXUAL MISCONDUCT .... 8:181

BREAKING THE AgE BARRIER IN ALASKA: INCLUding AdUlT CHILDREN IN LOSS OF FILIAL CONSORTIUM ACTIONS.

CONSTRUCTION AND AdMISSIBILITY OF INSURANCE POLICIES THAT PROVIDE COVERAgE For Punitive DaMAgE AwARDS, THE.

DAMAGES FOR A DECEDENT'S PRE-IMPACT FEAR: AN ELEMENT OF DAMAGES UNDER ALASKA'S SURVIVORSHIP STATUTE

DAMAGES FOR WRONGFUL DEATH IN ALASKA

DEFINING “RECKLESS DISREGARD” IN DEFAMATION SUITS: THE AlASKA SUPREME COURT RENDERS A NARROW INTERPRETATION OF THE NEW YORK TIMES RULE

EMPLOYMENT AT Will IN ALASKa: THE QUESTION OF PUBLIC POLICY TORTS

EVALUATION OF EARNINGS LOSS IN AlASKA COURTS: THE IMPLICATIONS OF BEAULIEU AND GUINN, THE.

LIABILITY OF THE STATE AND ITS EMPLOYEES FOR THE NEGLIGENT INVESTIGATION OF CHILD ABUSE REPORTS

Limits OF LiABILITY: CAN AlASKA OIL SPILl Victims RECOVER PURE ECONOMIC LOSS?, THE

Negligence Per Se and Broad Statutory Construction in Alaska: The Adoption of an ApPlicable StATUTE as AN APPROPRIATE STANDARD OF CARE

ProduCtS LIABILITY IN ALASKA - A PRACTITIONER's OVERVIEW...

Prospective APPlicAtion OF THE Restatement (THIRD) OF TORTS: Products LIABILITY IN ALASKA

SEAT BELT ISSUE: JUdICIAL DISREGARD FOR LEGISLATIVE ACTION, THE ................... 4:387

Sexual Abuser Insurance in Alaska: A Note on ST. PaUl Fire \& MARINE INS. CO. V. F.H.; K.W

SOVEREIGN IMMUNITY AND THE DISCRETIONARY FUNCTION EXCEPTION OF THE ALASKA TORT ClAIMS ACT..

TORT Loss Allocation AmOng JoInt TorTFEAsors In AlaskA: A CALL FOR COMPARATIVE CONTRIBUTION

TORT REFORM IN ALASKA: MUCH AdO ABOUT NOTHING? 


\section{TRUSTS AND ESTATES}

ALASKA DYNASTY TRUST, THE

UNDERSTANDING AND MAKING THE NEW SECTION 646 ELECTION FOR ALASKA

NATIVE SETTLEMENT TRUSTS

\section{WORKERS' COMPENSATION}

AlASKa WORKERS' COMPENSATION LAW: FACT-Finding, APPELlate REVIEW, AND THE PRESUMPTION OF COMPENSABILITY, THE

\section{AUTHOR INDEX TO ARTICLES, COMMENTS AND REPLIES}

VOLUME \& PAGE

BAIRD, RonAlD L., Easement Condemnation and State v. Doyle: Fair Market Value Without a Market $6: 199$

Bankston, William M. And SteVen T. O'HARA, The Creation, Operation, and Dissolution of a Limited Partnership in Alaska. $2: 271$

BEDERMan, DAVID J., High Stakes in the High Arctic: Jurisdiction and Compensation for Oil Pollution from Offshore Operations in the Beaufort Sea .....

BLACK, KATHRYN A., DAVID H. BUNDY, CYNTHIA PICKERING CHRISTIANSON AND CABOT CHRISTIANSON, When Worlds Collide: Alaska Native Corporations and the Bankruptcy Code

BLURTON, DAVID M., ANCSA Corporation Lands and the Dependent Indian Community Category of Indian Country

Blurton, David M., Canons of Construction, Stare Decisis and Dependent Indian Communities: A Test of Judicial Integrity...

BRADLEY, M. KATHERYN AND DEBORAH L. WILliAMs, "Be It Enacted by the People of Alaska ...”- - A Practitioner's Guide to Alaska's Initiative Law

CARns, Teresa White AND John Kruse, A Re-Evaluation of Alaska's Plea Bargaining Ban

Clarkson, Kevin G., David Orgon CoOlidge and William C. DunCan, The Alaska Marriage Amendment: The People's Choice on the Last Frontier...

Cravez, PAMEla, A Revolt in the Ranks: The Great Alaska Court-Bar Fight

CROFT, CHANCY, Something More Important Than Money - Vocational Rehabilitation in Workers' Compensation Cases.

CROOK, PENNy LOZON, Employment at Will: The "American Rule" and its Application in Alaska

CROSBy, DAVID C., The Constitutionality of Sobriety Checkpoints in Alaska.................... 8:227

Di PIETRo, SuSANNE, The Development of Appellate Sentencing in Alaska ....................... 7:265

Di Pietro, SusAnne, Foreword to Native Law Selections: Recent Developments in Federal Indian Law as Applied to Native Alaskans ....................................................... 10:333

Di Pietro, Susanne, Tribal Court Jurisdiction and Public Law 280: What Role for

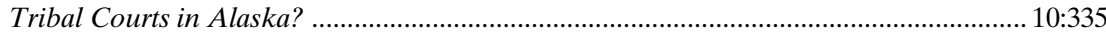

Di Pietro, SusAnNe And Teresa W. CARns, Alaska's English Rule: Attorney's Fee Shifting in Civil Cases

Di PIETRO, SUSANNE AND TERESA W. CARns, Improving the Court Process for Alaska's Children in Need of Aid

Dropkin, Drew D. AND JAMES H. MCCOMAs, On a Collision Course: Pure Propensity Evidence and Due Process in Alaska

EDWARDS, BRUCE N., Understanding and Making the New Section 646 Election for Alaska Native Settlement Trusts. 
VOLUME \& PAGE

Feldman, JefFrey M. And Stuart A. Ollanik, Compelling Testimony in Alaska: The Coming Rejection of Use and Derivative Use Immunity ............................................. 3:229

Fessler, Daniel William, The Alaska Corporations Code: The Forty-Ninth State Claims the Middle Ground

FISHER, GREGORY S., A Brief Analysis of After-Acquired Evidence in Employment Cases: A Proposed Model for Alaska (and Points South)....

FisHER, GREGORY S., After Acquiring an Audience: A Brief Reply to the June 2001 Critique Regarding After-Acquired Evidence $18: 287$

FitZGERALD, JOHN RICHARD, An Analysis of Jurisdictional Issues Presented When State-Employed Seamen Are Injured and Seek Redress..

FORD, MARILYN J. WARD, Indian Country and Inherent Tribal Authority: Will They Survive ANCSA?

Fossey, W. RICHARD, Employment Discrimination Law - Strand v. Petersburg Public School and Fridriksson v. Alaska USA Federal Credit Union: The Supreme Court Charts an Uncertain Course...

FOSSEY, W. RICHARD, Meiners v. Bering Strait School District and the Recall of Public Officers: A Proposal for Legislative Reform.

Fossey, W. RichaRd AND JOHN M. SEDOR, In re Copper River School District: Collective Bargaining and Chapter 9 Municipal Bankruptcy

Frost, JR., Don J., Amoco Production Co. v. Village of Gambell and Motor Vehicle Manufacturers Association v. State Farm Mutual Automobile Insurance Co.: Authority Warranting Reconsideration of the Substantive Goals of the National Environmental Policy Act

Gostin, Lawrence O. And James G. Hodge, JR., The Public Health Improvement Process in Alaska: Toward a Model Public Health Law.

GREEN, STEVEN KeITH, Freedom of Religion in Alaska: Interpreting the Alaska Constitution.

GREENSTEIN, MARLA N., Judicial Disqualification in Alaska Courts ............................... 17:53

GREER, STEPHEN E., The Alaska Dynasty Trust .............................................................. 18:253

HANLEY, PAT, Warrantless Searches for Alcohol by Native Alaskan Villages: A Permissible Exercise of Sovereign Rights or an Assault on Civil Liberties? .................... 14:471

Hollomon, DunCAN, The Struggle for Alaska's Submerged Land ....................................5:69

INGRAHAM, MiLlard F., Damages for Wrongful Death in Alaska................................... 5:293

JOHNSON, CARL H., A Comity of Errors: Why John v. Baker is Only a Tentative Step in the Right Direction...

JONES, G. KEVIN, Major Issues in Developing Alaska's Outer Continental Shelf Oil and Gas Resources

KeYES, LAURENCE, Alaska's Apportionment of Damages Statute: Problems for Litigants .....

KNUTH, MARGOT O., Inspection and Discovery of State Records in Alaska ......................... 4:277

LARSOn, ARTHUR AND JOHn LewIS, The Alaska Workers' Compensation Law: FactFinding, Appellate Review, and the Presumption of Compensability ...................................2:1

MATAL, JOSEPH D., A Revisionist History of Indian Country ......................................... 14:283

Matthews, Thomas A., Products Liability in Alaska - A Practitioner's Overview .......... 10:1

MCCUNE, G. BLAIR, Overview of Juvenile Delinquency Law in Alaska, An ......................... 8:1

McCune, Blair, Self-Incrimination Protection Under the Alaska Constitution: A Descriptive Analysis

McGreal, Paul E., A Tale of Two Courts: The Alaska Supreme Court, the United States Supreme Court, and Retroactivity ........................................................................ 9:305

McGreal, Paul E., Alaska Equal Protection: Constitutional Law or Common

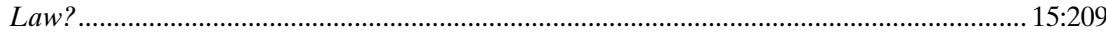

MESCHEWSKI, JAMES A., Choice of Law in Alaska: A Survival Guide for Using the Second Restatement. 
Metzloff, Thomas B., Alternative Dispute Resolution Strategies in Medical Malpractice

Mitchell, Donald CRAIG, Alaska v. Native Village of Venetie: Statutory Construction or Judicial Usurpation? Why History Counts

Moberly, Michael D. AND LAURA L. FARLEY, Blowing Hot and Cold on the Frozen Tundra: A Review of Alaska's Quasi-Estoppel Doctrine.

Moberly, Michael D., Philip J. Moberly AND LAURA L. FARLEy, Walt-zing Through an Employment Termination: Is There a Duty to Investigate Before Discharging in Alaska?

Nelson, Ronald L., Welcome to the "Last Frontier," Professor Gardner: Alaska's Independent Approach to State Constitutional Interpretation ..

Noble, HeAther, Tribal Powers to Regulate Hunting in Alaska

Nordstrand, ScOtT J. AND PAUl D. SEYFerth, Private Rights Versus Public Power: The Role of State Action in Alaska Constitutional Jurisprudence...

ORLANSKy, SUSAN AND JEFFREY M. FELDMAN, Justice Rabinowitz and Personal Freedom: Evolving a Constitutional Framework.

Osowski, Shane J., Alaska Distress Law in the Commercial Context: Ancient Relic or Functional Remedy?

PARKS, RICHARD W., The Evaluation of Earnings Loss in Alaska Courts: The Implications of Beaulieu and Guinn ...

Pengilly, Charles R., Post-Plea Appeal of "Dispositive” Issues: “There's Glory for You!”.

PengILly, Charles R., Restitution, Retribution and the Constitution ............................... 7:333

QUARLES, STEVEN P. AND THOMAS R. LUNDQUist, The Alaska Lands Act's Innovations in the Law of Access Across Federal Lands: You Can Get There from Here.

QUINN, EMILY D., Standards of Materiality Governing the Prosecutorial Duty to Disclose Evidence to the Defense.

SACKS, JEREMY DAVID, Culture, Cash or Calories: Interpreting Alaska Native Subsistence Rights

SEYFERTH, PAUL D., The Construction and Admissibility of Insurance Policies that Provide Coverage for Punitive Damage Awards.

STEBING, DAvid G., Insurance Regulation in Alaska: Healthy Exercise of a State Prerogative.

STERN, BARRY JEFFrey, Consciousness of Wrongdoing: Mens Rea in Alaska ....................... 1:1

STERN, BARRY JEFFREY, Presumptive Sentencing in Alaska .............................................. 2:227

STERN, BARRY JEFFREY, Rethinking Manifest Injustice: Reflections Upon the Decisions of the Three-Judge Sentencing Panel.

STRICKLAND, SHERIDAN, Municipality of Anchorage v. Hitachi Cable, Ltd. - Time

for Adoption of a Void Contract Remedy for Alaska Public Contracting Authorities

Sullivan, Jennifer L., The Spirit of '76: Does President Clinton's Roadless Lands Directive Violate the Spirit of the National Forest Management Act of 1976?

Sutherland, Earl M., One Client, One Defense: Revisiting CHI with the Alaska Rules of Professional Conduct...

Van Flein, Thomas V., Prospective Application of the Restatement (Third) of Torts: Products Liability in Alaska.

Venneberg, Terry A., After-Acquired Evidence in Employment Cases in Alaska: An Alternative Approach.....

WHite, STEPHEN M., "Equal Access" to Alaska's Fish and Wildife.

Wilkens, James K. AND Thomas A. MatTHEWs, A Survey of Federal Tax Collection Procedure: Rights and Remedies of Taxpayers and the Internal Revenue Service. 
WiSE, Michael B., Northern Lights - Equal Protection Analysis in Alaska.

ZALEHA, D. BERNARD, Alaska's Criminalization of Refusal to Take a Breath Test: Is

It a Permissible Warrantless Search Under the Fourth Amendment? ..

\section{AUTHOR INDEX TO NOTES}

AвBOtT, SUSAN LYNN, Liability of the State and Its Employees for the Negligent Investigation of Child Abuse Reports $10: 401$

AleXANDer, KAmla, A Modest Proposal: The "Reasonable Victim" Standard and Alaska Employers' Affirmative Defense to Vicarious Liability for Sexual Harassment... .

ALTES, SCOTT LAWRENCE, The Statute of Limitations for Professional Malpractice in Alaska After Lee Houston \& Associates, Ltd. v. Racine 9:41

ANTIPOLO, VIRGINIA CELLA, The Impact of Economic Incentives on the Award of Attorney's Fees in Public Interest Litigation .. 1:189

ARONIE, JonAthan SCOTT, Alaska's Medical Malpractice Expert Advisory Panel: Assessing the Prognosis.....

AVILES, KAREN A., Eidelson v. Archer: Exhaustion of Remedies in a Private Hospital...

BAKER, C. MARK, Riley v. Northern Commercial: Commercial Rationale Triumphs Over Statutory Interpretation ....

BALUSS, JANE, Mandatory Mediation of Coastal Zone Planning Disputes in AlaskaAn Innovative Approach to Administrative Decisionmaking..

Bostleman, William L., Aspen Exploration Corp. v. Sheffield: The Status of Official Immunity in Alaska.

BRUMBAugh, KAREN B., Wanberg v. Wanberg: Characterization of Property for the Purpose of Equitable Distribution

BRUYNES, IRENE W., Strict Liability and the Admissibility of Evidence of Subsequent Remedial Measures Under Evidence Rule 407.

BRYNER, WILliam M., Toward a Group Rights Theory for Remedying Harm to the Subsistence Culture of Alaska Natives...

ButT, JefFrey DREW, The Indian Child Welfare Act: Does It Cover Custody Disputes Among Extended Family Members?....

CARROLL, RoBERT, Litigation-Ending Sanctions: Alaska Courts' Use of Rule 37.

CASTEllon, Michael C., Standing to Challenge the Disposition of Land in Alaska: A Proposed Remedy for the Inadequacies in the Current Case Law .....

CASTLETon, Thomas E., A Matter of Expectations: Interpreting the Statutory

Preemption of Local Assistance to Federal Firearms Regulators

CASTRO, BRIAN M., Smothering Freedom of Association: The Alaska Supreme Court Errs in Upholding the State's Blanket Primary Statute.

ClaPaCs, GRantland M., "When in Nome ...": Custom, Culture and the Objective Standard in Alaskan Adverse Possession Law .

Clarke, B. NeIL S., Shareholders' Agreements in Alaska After Hikita v. Nichiro Gyogyo Kaisha, Ltd.

CoHEn, JoEl Michael, Nitz v. State: Skewing the Evidentiary Rules to Prosecute Child Molesters

COLLINS, JefFreY D., Alaska Rule 26: A Quixotic Venture Into the World of Mandatory Disclosure.

CONNOlly, WARD S., Sexual Abuser Insurance in Alaska: A Note on St. Paul Fire \& Marine Ins. Co. v. F.H.; K.W.

CoOK, Richard N., Drug Testing of Public and Private Employees in Alaska .....

CURETON, FrAnK W., The Reportorial Power of the Alaska Grand Jury.. 
Davis, Thomas P., Civil Rule 90.3: Judicial Discretion Under Alaska's Child Support Guideline. $8: 251$

DeBusk, Susan E., Alaska's Insanity Defense and the "Guilty but Mentally Ill" Verdict

DosIER, DENISE, The Clouds Are Lifting: The Problem of Title to Submerged Lands

in Alaska...

EISENSCHMIED, NANCY L., Lesser-Inchuded Offenses in Alaska: State v. Minano............. 8:271

EISENSCHMIED, NANCY L., Lesser-Included Offenses in Alaska: State v. Minano

ERB, JASON R., The Implied Covenant of Good Faith and Fair Dealing in Alaska: One Court's License to Override Contractual Expectations.

Fishel, Alan, Pears v. State: An Improper Application of Alaska's Current Law to

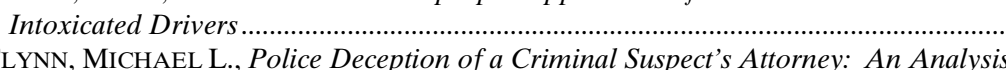

FlynN, MiChAEl L., Police Deception of a Criminal Sus
of Moran v. Burbine Under the Alaska Constitution $11: 35$

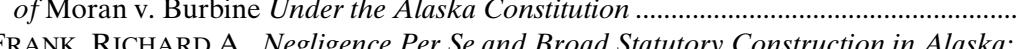

The Adoption of an Applicable Statute as an Appropriate Standard of Care

Frost, JR., Don J., Preliminary Injunctions as Relief for Substantial Procedural Violations of Environmental Statutes: Amoco Production Co. v. Village of Gambell .... 5:161

GiBBS, A. GREGORY, Anchorage: Gaming Capital of the Pacific Rim

GotCH, JR., JosePH E., Creditors' vs. Debtors' Rights Under Alaska Foreclosure Law: Which Way Does the Balance Swing?

GREENE, DAVID A., Investigative Stops in Alaska: Can Coleman Survive a Multifactored Balance? 2:409

Grossbauer, John F., Alaska's Right to Privacy Ten Years After Ravin v. State: Developing a Jurisprudence of Privacy

GuSTAFSON, MARK D., Custodial Consents to Search in Alaska: A Waiver Approach, at Least Where Miranda Warnings Are Absent?

HAMMAR, Julian E., Breaking the Age Barrier in Alaska: Including Adult Children in Loss of Filial Consortium Actions. $7: 381$

Hardgrove, SANDrA J., Local Hire Laws: Alaska's Futile Attempts at Preferential Treatment.....

Harrington, Robert E., Alaska's Public Duty Exception: Restraints upon the Right to Contractual Indemnity.

HARRISON, LOU, Hammond v. North Slope Borough: The Endangered Species Issue - An Exercise in Judicial Lethargy ...

HARRISON, LOU, Managing Sensitive Ecosystems: Honsinger v. State and the Need for Flexibility in the Rules of Real Property

HeAdley, Darah S., The Alaska Supreme Court and the Rights of Public School Teachers as Employees: A Suggested Response to Judicial Limitation of Collective Bargaining Rights......

HeMmerich, Michael R., The Constitutionality of Alaska's Takeover Bid Disclosure Act . . $3: 331$

Hunter, ShymeKa L., More Than Just a Private Affair: Is the Practice of Incarcerating Alaska Prisoners in Private Out-of-State Prisons Unconstitutional? $1: 129$ OHnson, Elizabeth A., Alaska Pacific Assurance Co. v. Brown: The Right to Travel and the Constitutionality of Continuous Residency Requirements

Jones, Celia GRASTY, Nelson v. Nelson: A Proposal for Equitable Distribution of the Professional Degree.

JONES, NANCY K., Defining an "Investment Contract" for Purposes of Alaska Blue Sky Law: Have the Alaska Courts Stretched Their Test Beyond Meaningful Application?

KAPLAN, JOHn STUART, The Mental Health Land Trust Litigation: State v. Weiss and its Aftermath 
VOLUME \& PAGE

Kenyon, M. Kathleen, Alaska's “Quasi-Public” Hospitals: The Implications of

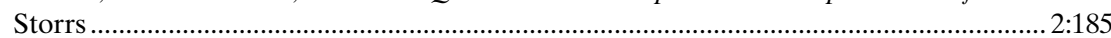

KordZIEL, KEVIN M., Rule 82 Revisited: Attorney Fee Shifting in Alaska ...................... 10:429

KoRNFIELD, PHOEBE, The Enforceability of Forum-Selection Clauses After Stewart Organization, Inc. v. Ricoh Corporation

KurTZ, M. DAVID, Managing Alaska's Coastal Development: State Review of Federal Oil and Gas Lease Sales ......................................................................................... 11:377

KuSHNER, DAVID, Free Exercise, Fair Housing and Marital Status — Alaskan Style...... 12:335

LAM, BRIAn E., The Admissibility of Prior Bad Acts in Sexual Assault Cases Under Alaska Rule of Evidence 404(b) - An Emerging Double Standard....... $5: 193$

LeATHerwood, Leslie A., Sanity in Alaska: A Constitutional Assessment of the Insanity Defense Statute.

LEWIS, CHRISTINA L., The Exploitation of Trust: The Psychotherapist-Patient Privilege in Alaska as Applied to Prison Group Therapy..

LEWIS, DAVID P., The Limits of Liability: Can Alaska Oil Spill Victims Recover Pure Economic Loss?.

MAHONEy, KeVIN S., Alaska's Cap on Noneconomic Damages: Unfair, Unwise and Unconstitutional

MAJEWSKI, AMY L., Inconsistent Jury Verdicts Returned on a Multiple Count Indictment of a Single Defendant.. $3: 387$

MARINACCIO, III, LEONARD, Out on Parol?: A Critical Examination of the Alaska Supreme Court's Application of the Parol Evidence Rule.

MASON, GARY EDWARD, Lawrence v. Lawrence: The Use of Rule 60(b) Motions Based upon Post Judgment Changes in Controlling Law.

MAY, KIMBERLY S., Shifting Away from Rehabilitation: State v. Ladd's Equal Protection Challenge to Alaska's Automatic Waiver Law.

MCDANnell, Jennifer K., Assignability of Legal Malpractice Claims ....

MeYer, JEANNE AND Jim O. STUCKEY, II, Deterring Defendants from Taking the Stand: The Extension of State v. Wickham to Rule 404(b)...

Mills, DAVID EDWARD, Tort Loss Allocation Among Joint Tortfeasors in Alaska: A Call for Comparative Contribution.

Murphy, SeAn Kendall, Pouring Nonprobate Assets Into a Testamentary Trust: A Half-Protected Activity in Alaska

NAZARIAn, Douglas R., Catholic Social Services, Inc. v. C.A.A.: Best Interests and Statutory Construction of the Indian Child Welfare Act ..

NELSON, CHRISTOPHER D., Toward a Compensatory Model of Alimony in Alaska ....... 12:101

Orgill, Marcia SwiHart And Bellanne Meltzer Toren, Sovereign Immunity and the Discretionary Function Exception of the Alaska Tort Claims Act... 2:99

OWENS, III, THOMAS P., Employment at Will in Alaska: The Question of Public Policy Torts.

Peterson, Thomas W., The Doctrine of the Implied Insured in Alaska: Recent Developments Concerning Third Parties to Insurance Contracts..

Pettit, Kenton K., The Waiver of Tribal Sovereign Immunity in the Contractual Context: Conflict Between the Ninth Circuit and the Alaska Supreme Court? ............... 10:363

Plissey, STEVEn D., Compulsory Joinder of Partial Subrogees: Implications of the Alaska Rule.....

POMERAnZ, JAmes R., The State of Caveat Emptor in Alaska as it Applies to Real Property

QUIGLey, KATHERINE, Converting to a Limited Liability Company: Considerations for Alaska Business Organizations.

READ, JOHN R., Thomas v. Anchorage Telephone Utility: Alaska Tackles GenderBased Wage Discrimination 
REDMILES, MARK A., Shelter from the Storm: The Need for Wrongful Discharge Legislation in Alaska

REISS, BENJAMIN L., Alaska's Mens Rea Requirements for Statutory Rape....... 6:321

RobB, Cliona Mary, Bad Samaritans Make Dangerous Precedent: The Perils of Holding an Employer Liable for an Employee's Sexual Misconduct..... 9:377

Roper, PAMEla Forrestall, Hitting Deadbeat Parents Where it Hurts: "Punitive" Mechanisms in Child Support Enforcement ...

Rowe, JAMES S., Protection of Child Witnesses and the Right of Confrontation: A Balancing of Interests

Rutledge, JOYCE S., Monitoring the Employment Contract in Alaska. $7: 223$

SCOTT, INARA K., A Model for Alaska: Deregulation in the Far North ............................. 16:329

SHAPIRO, DAVID G., Jurisdiction and the Hunt: Subsistence Regulation, ANILCA and Totemoff $14: 115$

Simon, Jeremy S., Privacy vs. Practicality: Should Alaska Adopt the Leon Good Faith Exception?.

SMITH, LAURENCE S., A Proposed Solution to the Federal Taxation of Alaska Permanent Fund Dividend Payments.

StARK, SANFORD WeIL, Abandonment v. Adoption: Terminating Parental Rights and the Need for Distinct Legal Inquiries.

Stegemoeller, Andrew B., Defining "Reckless Disregard" in Defamation Suits: The Alaska Supreme Court Renders a Narrow Interpretation of the New York Times Rule

STEIN, TERRI, The Seat Belt Issue: Judicial Disregard for Legislative Action...................... 4:387

StidVent, Christopher T., Tort Reform in Alaska: Much Ado About Nothing? ........... 16:61

STRAuSs, PHILIP REED, Control and/or Misconduct: Clarifying the Test for Piercing the Corporate Veil in Alaska

SYDNOR, II, THOMAS D., Damages for a Decedent's Pre-Impact Fear: An Element of Damages Under Alaska's Survivorship Statute.

Thesing, JR., W. Joseph, Alaska Rule of Civil Procedure 11: A Proposed Amendment and $a$ Guide for Application and Interpretation... $3: 361$

Tribble, Bradford J., Prison Overcrowding in Alaska: A Legislative Response to the Cleary Statement..

Veit, Jeremy M., Self-Settled Spendthrift Trusts and the Alaska Trust Act: Has Alaska Moved Offshore?

WARREn, PATricia J., Rosenberg v. Smidt: Dramatic Ramifications for Nonjudicial Foreclosure Sales in Alaska?.

WeISS, JON DAVID, A Taxing Issue: Are Limited Entry Fishing Permits Property? ........... 9:93

Wells, JR., Charles TAlley, Protecting Alaska's Children from Neglect: The Appropriate Legislative Response to In re S.A. and R.J.M. v. State

WiLliams, CAMERON J., Sidestepping Scott: Modifying Criminal Discovery in Alaska.....

Williams, CARol R., A Proposal for Protecting Privacy During the Information Age

WINTERS, ANDREW S., Ravin Revisited: Do Alaskans Still Have a Constitutional Right to Possess Marijuana in the Privacy of Their Homes?

WITZLEBEN, BEA, Visitation Rights for Natural Parents After Stepparent Adoption .......... 1:319

WoOds, MICHELE J., The Adoption of the ABA Standards for Imposing Lawyer Sanctions by the Alaska Supreme Court - In re Buckalew...

Zarou, Mechelle, The Good, the Bad, and the Ugly: Drug Testing by Employers in Alaska 
VOLUME \& PAGE

\section{AUTHOR INDEX TO BOOK REVIEWS}

Anderson, Robert T., Review of Alaska Natives and American Laws, Second 